\title{
IDENTIFICATION OF BACTERIAL FLORA ISOLATED FROM APPARENTLY HEALTHY WATER BIRDS OF DHAKA ZOO OF BANGLADESH
}

\author{
M. A. H. Sarker ${ }^{1}$, M. Jahan ${ }^{2 *}$, M. N. Parvin ${ }^{1}$, M. A. Malek ${ }^{1}$ and M. T. Hossain ${ }^{1}$ \\ ${ }^{1}$ Department of Microbiology and Hygiene, Faculty of Veterinary science, Bangladesh Agricultural University, \\ Mymensingh-2202, Bangladesh, ${ }^{2}$ Department of Physiology and Pharmacology, Faculty of Veterinary Medicine \\ and Animal Science, Bangabandhu Sheikh Mujibur Rahman Agricultural University, Gazipur-1706.
}

\begin{abstract}
A total of 72 samples (Oral swab, cloacal swab and faeccal sample) were aseptically collected from different species (Purple Heron, Demoiselle Crane Pond Heron (adult), Pond Heron (young), Cattle Egret, Night Heron (adult), Night Heron (young) and Little Cormorant) of apparently healthy water birds of Dhaka Zoo of Bangladesh for The isolation and identification of bacterial flora. All the collected samples were inoculated in different bacteriological media for the study of their cultural properties. Gram's staining, motility test and biochemical tests were also performed for the proper diagnosis of the isolated bacteria. Slide agglutination test was also performed to confirm the suspected Salmonella. Five types of bacteria were isolated and identified. The antibiogram of five randomly selected isolated bacteria of each genus were also studied. Among the isolated bacteria the isolation rate of E. coli was $54.16 \%$ followed by Salmonella spp. $31.94 \%$, Staphylococcus spp. 27.78\%, Bacillus spp. $26.38 \%$ and Proteus spp. 8.33\%. Among the isolates, E.coli was found to be most prevalent bacteria. Among the samples the isolation rate of bacteria was higher in cloacal swab $54.16 \%$, followed by oral swab $51.38 \%$ and faecal sample $43.05 \%$. There was marked variation in the antibiotic sensitivity and resistant patterns of the isolated bacteria to the antibiotics available in the markets. It was found that most of the isolated bacteria were highly sensitive to enrofloxacin and norfloxacin. Ampicillin and furazolidone could not affect the growth of any isolated bacteria.
\end{abstract}

Key words: Bacterial species, isolation, identification, aquatic birds.

\section{INTRODUCTION}

The term "water bird" refers to bird species dependent on aquatic habitats to complete portions of their life cycles (http://www.waterbirdconservation.org). "Water Birds" is an informal name for a group including many though by no means all of the families that make their livings in the water (Hackett et al., 2008). Water birds constitute a natural resource of great intrinsic, human, and ecological value. They are conspicuous representatives of their exotic, mysterious, and wild aquatic worlds. Throughout history, they have figured prominently in human culture, serving as sources of food and ornamentation, as well as folkloric or totemic figures. Birds and their diversity have been considered as good indicators of ecosystem health and in the UK, bird diversity is used as one of 15 quality of life indicators (Gregory et al., 2003). There are a number of different bacterial infections that birds commonly get. In most cases the birds are probably susceptible to these infections due to underlying problems that have allowed for a large bacterial population to overwhelm their normal immunity, or the birds themselves are already weakened due to stress, poor nutrition, or poor husbandry. Bacterial infections can affect any of the organ systems, yet the most common infections affect the upper respiratory tract or sinuses, the intestinal tract and liver, the urinary tract, the reproductive tract, and the skin and feather follicles (http://www.animalhospitals-usa.com/birds/bird_diseases.html). Birds are susceptible to various kinds of bacterial diseases. Most common avian bacterial pathogens have been isolated from water birds, including Pasteurella multocida, Mycobacterium avium, M. tuberculosis, Salmonella spp., Clostridium spp., Erysipelothrix spp., E. coli, Streptococcus spp. and Staphylococcus spp. (Thomas et al., 2000).

*Corresponding e-mail address: marefa2011@gmail.com.

Copyright (C) 2012 Bangladesh Society for Veterinary Medicine

All rights reserved 0241/2012 


\section{A. H. Sarker and others}

Zoonotic Gram-negative bacteria previously isolated from seabird species include, but are not limited to Salmonella spp., Campylobacter spp., and Yersinia spp. (Kapperud and Rosef, 1983). Birds can act as vectors for spreading diseases such as psittacosis, salmonellosis, campylobacteriosis, mycobacteriosis (avian tuberculosis), avian influenza (bird flu), giardiasis, and cryptosporidiosis over long distances. Some of these are zoonotic diseases that can also be transmitted to humans, all of which are potentially important sources of mortality and reduced fitness in bird populations. These bacteria may also cause disease in domestic animals including poultry (Reed et al., 2003). Dhaka Zoo is the home to more than 2,000 animals from 165 species. The aviaries at the Dhaka Zoo house more than 1,200 birds from 90 species, among them water birds are more than 200 (http://www.bangladesh.com/sights/dhaka-zoo). As the water birds may help to transmit some diseases to man, it is very important to check the presence of any harmful bacteria in the birds of the zoo.

There is no literature on isolation of bacteria from water birds of Dhaka zoo. So the present study was under taken to isolate and identify important species of bacteria from apparently healthy water birds of Dhaka zoo along with cultural, biochemical, serological characteristics and antibiotic sensitivity pattern of the isolated bacteria.

\section{MATERIALS AND METHODS}

\section{Collection of sample and isolation of microflora}

A total of 72 oral swab, cloacal swab and faecal samples, 24 of each, were collected from 6 (Purple Heron, Demoiselle Crane, Pond Heron (adult), Pond Heron (young), Cattle Egret, Night Heron (adult), Night Heron (young) and Little Cormorant) different species of apparently healthy water birds of Dhaka Zoo, Mirpur, Dhaka. Each sample was inoculated in sterile nutrient both (NB) and transported to the bacteriology laboratory of the Department of Microbiology and Hygiene, BAU, Mymensingh, Bangladesh using ice flask immediately after collection. Inoculated nutrient broths were incubated at $37^{\circ} \mathrm{C}$ for 24 hours in bacteriological media and after 24 hours the incubated broth were streaked into different bacteriological media such as NA, EMB, MC, SS, BGA, BA, TSI (Himedia, India) to obtain pure culture of the bacteria.

\section{Preservation of stock culture}

Twenty percent sterile buffered glycerin and NA slant with liquid paraffin was used to preserve the isolated bacteria for further study (Buxton and Fraser, 1977).

\section{Morphology and motility study}

Gram's staining was performed to study the morphology of bacterial isolates (Merchant and Packer, 1967) and motility test was performed to differentiate motile bacteria from non-motile one (Cowan, 1985).

\section{Biochemical study}

Each isolated bacteria from each sample was biochemically identified by sugar fermentation test according to the procedure described by Cowan (1985), coagulase test according to Carter (1986) and catalase, indole test \&MR-VP test as per methods described by Cheesbrough (1984). Besides, triple sugar iron agar (TSI agar) slant was used to identify the lactose, saccharose and dextrose fermenters. The medium also helped to determine the ability of the organisms to produce hydrogen sulphide. The test organisms were heavily seeded with a platinum loop over the surface of the slants and stabbed into the butt of the TSI agar (Himedia, India). After incubation at $37^{\circ} \mathrm{C}$ for 24 hours, the tubes were examined for any change in the slant or butt (Cheesbrough, 1984).

\section{Hemolytic activity}

To determine the hemolytic property of isolated bacteria, the colonies of bacteria were inoculated on to Biood Agar (BA) media and incubated at $37^{\circ} \mathrm{C}$ for 24 hours. Various types of hemolysis were observed after the development of bacterial colony on the BA. The hemolytic pattern of the bacteria was categorized according to the types of hemolysis produced on BA and this was made as per recommendation of Carter (1986). 


\section{Slide Agglutination test}

Slide agglutination test was performed for the determination of the presence of specific capsular antigen against the Salmonella hyper immune serum (raised in chickens against Salmonella gallinarum and Salmonella pullorum) for the detection of the suspected bacteria as Salmonella. The test was performed according the protocol of Buxton and Fraser (1977). Briefly, one drop of capsular antigen was mixed with one drop of hyper immune serum on a clean glass slide and kept at room temperature for two minutes to observe the agglutination reaction. Clumping of cells on the slide was considered as positive and no clumping indicated the negative result.

\section{Antibiotic sensitivity tests}

To determine the drug sensitivity pattern of the isolated bacteria and to interpret their disease potential, commercially available antimicrobial discs (OXOID LIMITED Basingstoke, Hampshire, England) were used for the test. In vitro antibiotic sensitivity tests were done using disc diffusion test following the method described by Kirby-Bauser (Bauser et al., 1966). 1-2 ml of freshly growing broth culture were poured on to NA, EMB agar or BGA and spread uniformly. Antibiotic discs were placed apart on the surface of the inoculated plates aseptically with the help of a sterile forceps and incubated at $37^{\circ} \mathrm{C}$ for $24 \mathrm{hrs}$. After incubation the plates were examined and the diameters of the zone of inhibition were measured. Depending on the area of the zone diameters for individual antibiotic was recorded as highly sensitive, moderately sensitive, less sensitive and resistant.

\section{RESULTS AND DISCUSSION}

Staphylococcus spp., Bacillus spp., E. coli, Proteus spp. and Salmonella spp. were isolated from oral swabs, cloacal swabs and faecal samples of apparently healthy six different species of water birds in this study. Specific media and biochemical tests were used for the isolation and identification of bacteria which were previously suggested by Buxton and Fraser (1977), Cowan (1985) and Cheesbrough (1985). The cultural and biochemical properties revealed by the isolates in this study are in agreement with the reports of Buxton and Fraser (1977) and Cheesbrough (1984).

Among the isolated bacteria E. coli and Bacillus spp. were isolated from oral swab, cloacal swab and faecal samples. Middleton and Ambrose (2005) also isolated E. coli from faeces of migratory waterfowl. Staphylococcus spp. were isolated from oral swab and faecal samples which are similar to the findings of Tarello (2001) who also isolated Staphylococcus spp. from birds. Proteus spp. were isolated from oral swabs and Salmonella spp. were isolated from cloacal swabs and faecal sample. Dobbin et al. (2005) recovered Salmonella isolates from cloacal swab of ground-nesting Double-crested cormorant (DCC) chicks and Robert et al., (1974) isolated Salmonella typhimurium from young herons being held at the Patuxent Wildlife Research Center. In captive condition of zoo the isolation of the five genus of bacteria supports the findings of Hoar et al. (2007) who also isolated gram-positive cocci, coliforms, and gram-negative bacilli from whooping cranes and sandhill cranes housed at the Calgary Zoo.

Table1. Overall percentage of different types of bacteria isolated from different types of samples collected from water birds

\begin{tabular}{|lcccc|}
\hline & $\begin{array}{l}\text { Oral swab } \\
(\mathrm{n}=24)\end{array}$ & $\begin{array}{l}\text { Cloacal swab } \\
(\mathrm{n}=24)\end{array}$ & $\begin{array}{l}\text { Feces } \\
(\mathrm{n}=24)\end{array}$ & Total \\
\hline E. coli & $12(50)$ & $12(50)$ & $15(62.50)$ & $39(54.16)$ \\
Bacillus spp & $10(41.66)$ & $9(37.50)$ & $0(0)$ & $19(26.38)$ \\
Staphylococcus spp. & $9(37.50)$ & $0(0)$ & $11(45.83)$ & $20(27.78)$ \\
Salmonella spp. & $0(0)$ & $18(75)$ & $5(20.83)$ & $23(31.94)$ \\
Proteus spp. & $6(25)$ & $0(0)$ & $0(0)$ & $6(8.33)$ \\
\hline Total & $37(51.38)$ & $39(54.16)$ & $31(43.05)$ & \\
\hline
\end{tabular}

$\mathrm{n}=$ Number of examined samples 


\section{A. H. Sarker and others}

Table2. Overall percentages of different types of bacteria isolated from each type water birds $n=$ No. of samples examined from each type of water bird

\begin{tabular}{|c|c|c|c|c|c|c|c|c|}
\hline \multirow{2}{*}{$\begin{array}{l}\text { Name } \\
\text { of bacteria }\end{array}$} & \multicolumn{8}{|c|}{ Number $(\%)$ of different types of bacteria isolated from each type of water birds $(n=9)$} \\
\hline & $\begin{array}{l}\text { Purple } \\
\text { Heron }\end{array}$ & $\begin{array}{l}\text { Demoiselle } \\
\text { Crane }\end{array}$ & $\begin{array}{l}\text { Pond } \\
\text { Heron } \\
\text { (adult) }\end{array}$ & $\begin{array}{l}\text { Pond } \\
\text { Heron } \\
\text { (young) }\end{array}$ & $\begin{array}{l}\text { Cattle } \\
\text { Egret }\end{array}$ & $\begin{array}{l}\text { Night } \\
\text { Heron } \\
\text { (adult) }\end{array}$ & $\begin{array}{l}\text { Night } \\
\text { Heron } \\
\text { (young) }\end{array}$ & $\begin{array}{l}\text { Little } \\
\text { Cormorant }\end{array}$ \\
\hline E. coli & $9(100)$ & $5(55.56)$ & $6(66.67)$ & $3(33.33)$ & $2(22.22)$ & $3(33.33)$ & $5(55.56)$ & $6(66.67)$ \\
\hline Bacillus spp & $0(0)$ & $3(33.33)$ & $5(55.56)$ & $2(22.22)$ & $0(0)$ & $3(33.33)$ & $3(33.33)$ & $3(33.33)$ \\
\hline Staphylococcus spp & $.3(33.33)$ & $6(66.67)$ & $4(44.44)$ & $3(33.33)$ & $0(0)$ & $3(33.33)$ & $1(11.11)$ & $0(0)$ \\
\hline Salmonella spp. & $0(0)$ & $3(33.33)$ & $0(0)$ & $6(66.67)$ & $3(33.33)$ & $2(22.22)$ & $5(55.56)$ & $4(44.44)$ \\
\hline Proteus spp. & $1(11.11)$ & $0(0)$ & $0(0)$ & $0(0)$ & $2(22.22)$ & $0(0)$ & $0(0)$ & $3(33.33)$ \\
\hline Total & $13(18.06)$ & $17(23.61)$ & $15(20.83)$ & $14(19.44)$ & $7(9.72)$ & $11(15.27)$ & $14(19.44)$ & $16(22.22)$ \\
\hline
\end{tabular}

Among the three samples, the isolation of bacteria from cloacal swab (54.16\%) was higher followed by oral swab (51.38\%). But it is imperative to note that the bacterial load is usually higher in cloaca and feces than oral cavity of healthy birds (Petrak, 1982).

Table 3. Results of antibiotic sensitivity tests in percent

\begin{tabular}{|c|c|c|c|c|c|c|c|c|c|c|}
\hline & $\begin{array}{l}\text { Total } \\
\text { isolates }\end{array}$ & Sensitivity/ resistance & $\begin{array}{l}\% \\
\text { antil } \\
\end{array}$ & $\begin{array}{l}\text { isola } \\
\text { tics } \\
\end{array}$ & stra & hs & itive/ & resistar & & various \\
\hline & & & CIP & PEF & ENR & $\mathrm{CN}$ & AMP & NOR & AML & FR \\
\hline & & Resistance & 00 & 00 & 00 & 40 & 40 & 00 & 00 & 40 \\
\hline & & Less sensitive & 00 & 40 & 00 & 40 & 60 & 00 & 40 & 40 \\
\hline E. coli & 05 & Moderately sensitive & 20 & 20 & 40 & 20 & 00 & 20 & 60 & 20 \\
\hline & & Highly sensitive & 80 & 40 & 60 & 00 & 00 & 80 & 00 & 00 \\
\hline & & Resistance & 00 & 40 & 00 & 00 & 20 & 00 & 40 & 00 \\
\hline Staphylococcus & 05 & Less sensitive & 00 & 40 & 00 & 40 & 80 & 00 & 40 & 60 \\
\hline spp. & & Moderately sensitive & 40 & 20 & 60 & 60 & 00 & 20 & 20 & 40 \\
\hline & & Highly sensitive & 60 & 00 & 40 & 00 & 00 & 80 & 00 & 00 \\
\hline & & Resistance & 00 & 20 & 00 & 00 & 40 & 00 & 20 & 20 \\
\hline & & Less sensitive & 00 & 40 & 20 & 40 & 40 & 00 & 80 & 60 \\
\hline Bacillus spp. & 05 & Moderately sensitive & 20 & 40 & 80 & 60 & 20 & 20 & 00 & 20 \\
\hline & & Highly sensitive & 80 & 00 & 00 & 00 & 00 & 80 & 00 & 00 \\
\hline & & Resistance & 00 & 40 & 20 & 00 & 40 & 00 & 00 & 80 \\
\hline & & Less sensitive & 00 & 60 & 60 & 40 & 60 & 00 & 20 & 20 \\
\hline Salmonella spp. & 05 & Moderately sensitive & 20 & 00 & 20 & 60 & 00 & 60 & 40 & 00 \\
\hline & & Highly sensitive & 80 & 00 & 00 & 00 & 00 & 40 & 40 & 00 \\
\hline & & Resistance & 00 & 00 & 00 & 20 & 60 & 00 & 60 & 80 \\
\hline & & Less sensitive & 00 & 40 & 20 & 60 & 40 & 40 & 40 & 20 \\
\hline Proteus spp. & 05 & Moderately sensitive & 40 & 60 & 60 & 20 & 00 & 40 & 00 & 00 \\
\hline & & Highly sensitive & 60 & 00 & 20 & 00 & 00 & 20 & 00 & 00 \\
\hline
\end{tabular}

ENR = Enrofloxacin CIP $=$ Ciprofloxacin PEF $=$ Pefloxacin GN $=$ Gentamicin AMP $=$ Ampicillin NOR $=$ Norfloxacin AML $=$ Amoxycillin FR $=$ Furazolidone 
As the water birds maximum time remain in the water and usually eats raw fishes, bacterial isolation rate from oral swab may be higher compare to faecal samples. Irrespective to samples isolation rate of E.coli was $54.16 \%$ which was higher among the five isolated bacteria followed by $31.94 \%$ of Salmonella spp. and $27.78 \%$ of Staphylococcus spp. This indicates that E. coli is normally present in birds' body as commensal bacteria. Among the different types of water birds, overall lowest $9.72 \%$ of bacteria were isolated from Cattle Egret and highest $23.61 \%$ from Demoiselle Crane. But no remarkable variation was found in other types of birds in the percentage of bacterial isolates and literatures are not available to compare our findings with the others.

The sensitivity patterns of different bacteria to various antibiotics were so variable that it was difficult to interpret. The resistant patterns to antibiotics were found variable results in case of all isolates. On the other hand, the antibiotics of fluoroquinolone group such as ciprofloxacin, norfloxacin and enrofloxacin showed moderate to high sensitivity against almost all the bacterial isolates except Proteus spp. which was found highly sensitive to furazolidone. The results of anbiotic sensitivity pattern are somewhat similar with the findings of Ghosh et al. (2002), Saikia et al. (2002), Islam et al. (2004) and Gomes and Muniyappa (2007).

It was not possible to identify the isolated bacteria up to species level with their pathogenic nature. If it is possible to identify the isolated bacteria properly that will help to gain knowledge about the threat of the isolated bacteria for the water birds in captive condition.

\section{REFERENCES}

1. Buxton A and Fraser G (1977). Animal Microbiology. Blackwell Scientific Publications, Oxford, London, Edinburgh, Melbourne, 1: 85-110.

2. Carter GR (1986). Studies on Pasteurella multocida. A haemagglutination test for the identification of serological types. American Journal of Veterinary Research 16:4481-484.

3. Cheesebrough $M$ (1984). Medical Laboratory Manual for Tropical Counties. (Vol. 2: Microbiology), Tropical Health Technology/Butter-Worth and Co., Cambridgeshire/Kent. pp. 40-57.

4. Cheesebrough M (1985). Medical laboratory manual for tropical countries (Vol. 2: Microbiology), Tropical Health Technology/Butter-Worth and Co., Cambridgeshire/Kent. pp. 400-480.

5. Christopher J, Ronald BM, Lynne WM, Ruth SM, Duncan and Robert MC (1998). Avian Morbidity and Mortality from Botulism, Aspergillosis, and Salmonellosis at Jamaica Bay Wildlife Refuge, New York, USA. Colonial Waterbirds. 11(2):284-292.

6. Cowan ST (1985). Cowan and Steel's Manual for the Identification Medical Bacteria. $2^{\text {nd }}$ edn., Cambridge University Press, Cambridge, London. pp. 96-98.

7. Dobbin G, Hariharann H, Daoust PY, Hariharan S, Heaney S, Coles M, Price L and Muckle CA (2005). Bacterial flora of free-living Double-crested cormorant (Phalacrocorax auritus) chicks on Prince Edward Island, Canada, with reference to enteric bacteria and antibiotic resistance. Comparative Immunology, Microbiology and Infectious Diseases 28(1):71-82.

8. Gomes AR and Muniyappa L (2007). Antibiotic resistance and plasmid profile pattern of Escherichia coli of avian origin. Veterinary World 6(1): 12-13.

9. Gregory RD, Noble D, Field R, Marchant J, Raven M and Gibbons DW (2003). Using birds as indicators of biodiversity. Ornis Hungarica 13: 11-24.

10. Hackett SJ, Kimball RT, Reddy S, Bowie RCK, Braun EL, Braun MJ, Chojnowski JL, Cox WA, Han KL, Harshman J, Huddleston CJ, Marks BD, Miglia KJ, Moore WA, Sheldon FH, Steadman DW, Witt CC and Yuri T (2008). A phylogenomic study of birds reveals their evolutionary history. Science 320(5884):17631768.

11. Hoar BM, Whiteside DP, Ward L, Ingles GD and Morck DW (2007). Evaluation of the enteric microflora of captive whooping cranes (Grus americana) and sandhill cranes (Grus canadensis). Zoo Biology 26(2): $141-153$. 


\section{A. H. Sarker and others}

16. Islam MT, Islam MA, Samad MA and Kabir SML (2004). Characterization and antibiogram of Escherichia coli associated with mortality in broilers and ducklings in Bangladesh. Bangladesh Journal of Veterinary Medicine 2(1): 9-14.

17. Kapperud G, and Rosef O (1983). Avian wildlife reservoir of Campylobacter fetus subsp. jejuni, Yersinia spp., and Salmonella spp. in Norway. Applied and Environmental Microbiology. 45: 375-380

18. Merchant IA and Packer RA (1967). Veterinary Bacteriology and Virology. $7^{\mathrm{th}}$ edn., Iowa University Press, Ames, Iowa, USA. pp. 286-306.

19. Middleton JH And Ambrose A (2005). Enumeration and antibiotic resistance patterns of fecal indicator organisms isolated from migratory Canada geese (Branta canadensis). Journal of Wild Diseases. 41(2): $334-41$.

20. Reed KD, Meece JK, Henkel JS and Shukla SK (2003). Birds, Migration and Emerging Zoonoses: West Nile Virus, Lyme Disease, Influenza A and Enteropathogens. Clinical Medical Research. 1 (1):5-12.

21. Saikia M, Rahman H, Dutta PK. and Ali A (2002). Isolation and antibiogram of Salmonella from enteric infection in man and animals. Indian Journal of Comparative Microbiology, Immunology and Infectious Diseases. 23(2): 173-175.

22. Thomas CGA (1998). Gram Negative Bacilli in Medical Microbiology. $6^{\text {th }}$ edn. pp. 273-274. 